\title{
The pertinent role of forest inventory in making choice of silvicultural operations in community forests of Nepal
}

\begin{abstract}
S. G. Baral ${ }^{1 *}$, H. Vacik ${ }^{1}$, B. B. K. Chhetri ${ }^{2}$ and K. Gauli ${ }^{3}$
This paper explores the application of forest inventory to design silvicultural operations and its implementation to community forests. Four-time series forest inventory data (2005, 2010, 2013 and 2016) of Terai community forests were analysed, focusing on the type and size of tree removals from the forests. In addition, content analysis of the management plans of the forests was carried out and consultations were held with key informants. Though the forest inventory was prepared during the preparation of management plans, the results did not provide proper guidance on the selection of silvicultural operations, which were decided without a clear definition of the management objectives. They were very generic and largely ignored site-specific forest stand conditions. Most commonly practised silvicultural operations were cleaning and selective harvesting, which were similar for all forest blocks, though they varied in respect of forest stand conditions. The time series analysis of the inventory data showed that pole-sized trees were consistently removed in all four periods and emphasis was on extracting good quality trees without considering its effects on the stand. The study concludes that the current forest inventory is not very relevant in making a choice about silvicultural operations and the current practices might cause economic and ecological losses. Hence, we argued for identifying minimum forest management requirement necessary for the sustainable forest management that the silvicultural operations should be decided based on the management objectives and conditions of the forest, considering the ecological and economic value of the forest.
\end{abstract}

Key words: Community forest Nepal, inventory, management plan, silvicultural operation

$\mathrm{T}$

he Community Forestry Programme is one of the major national forest management strategies of Government of Nepal (Bartlett, 1992; Gautam, et al., 2004; Maryudi, et al., 2011; Gilmour, 2016) to restore forest and meeting subsistence need of forest dependent people. According to the Forest Rule 1995 and Community Forest Directives, 1995, the management plan of community forest should be prepared by the forest users with the support of District Forest Office. In 2000, Forest Department formulated "Guideline for Inventory of Community Forests" to assist the users and District Forest Office officials in assessing forests condition, estimating growing stock and annual allowable cut aiming to manage forests sustainably (DoF, 2000 p1). However, the Guidelines was debated for its technical soundness and managerial perspective.

The guidelines is often criticized for being conservative and protection-oriented which merely forbid cutting of green trees, allowed extraction of dead trees only rather than focusing on sustainable management of forests (Yadav, et al., 2009). Nevertheless, the Forest Act 1993 allows community forest user groups (CFUGs) to manage and utilize their Forests (CFs) under the guidance of the management plans. However, many of them are identical and emphasize more on protection than on adaptive contextual management (Branney and Yadav, 1998). The management plans mainly list the silvicultural operations, but not about the operation details.

Forest inventory plays a pivotal role in preparing inventory-based forest management plan (Toft, et $a l ., 2015)$ and enhancing the forest productivity

Institute of Silviculture, University of Natural Resources and Life Sciences, Vienna, Austria

*Email Corresponding author: sonybaral@gmail.com

${ }^{2}$ Institute of Forestry, Campus, Pokhara Nepal

The Deutsche Gesellschaft für Internationale Zusammenarbeit (GIZ), Nepal 
(Gilmour, 2016). Forest Department introduced silviculture-based management system i.e., scientific forest management in the $\mathrm{CF}$ in early 2013 (MFSC, 2014) for planning and harvesting of trees. It has received high priority after Forest Policy, 2014 and aims to increase forest productivity and production through sustainable management (MFSC, 2014a p.5). The policy requires to implement silviculture systembased management plan in community managed forest (MFSC, 2014 p.6). Further, the Forest Sector Strategy (2016-2025) emphasized for the development of management plans of forest in Nepal to ensure forest sustainability (MFSC, 2016 p.11). Subsequently, MFSC enacted silvicultural based forest management guidelines in 2014, known as "Scientific forest management guideline, 2014.

In course of forty years of community forests management, it achieved notable success in improving forest conditions and rural livelihoods (Acharya, 2002; Gautam, et al., 2004; Pokharel, et al., 2007; Poudel, et al., 2014; DFRS, 2015). While the first two decades of community forestry were mainly characterized by restoration of the forest; sustainable forest management remained in high priority, especially after the revision of the Forestry Policy in 2000. As a result, Forest Inventory Guidelines was enforced in 2000 to support harvesting decisions and to select appropriate silvicultural operations based on forest stand conditions. However, sustainable resource management practices, including silvicultural operations, are largely ignored in community-based forest management. Managing natural uneven-aged forest without considering appropriate silvicultural operations is one of the bottlenecks to maximising economic returns from the forest (Wang, 2004).

One of the main objectives in forest management is to meet societal needs e.g., forest products, ecosystem services, recreational opportunities. Managing forests in ways that can be 'closeto-nature' is one of the examples of alternative models of silviculture (Hara, 2016). Silviculture is both an art and a science. It is an art because it prescribes management objectives by considering forest owners' needs and it is a science because it assesses and collects information about a forest so that owners know its health conditions.
Silviculture is also known for helping chart out forest management roadmaps based on ground reality in order to meet the community's future needs. It provides a pathway to move and to formulate a plan for the future. Hobley (1996), explains participatory silviculture in relation to the conventional and scientific silviculture, and emphasizes linking both to social and institutional aspects and working together with forest technicians for development and implementation of management plans.

The silviculture techniques that are mostly used in Nepal are cleaning, singling, pruning, thinning, and harvesting of mature trees (Acharya, 2003; Yadav, 2009; Yadav, 2011, and Cedamon, et al., 2016). Inventories are drawn up for making standlevel decisions over a planning horizon e.g., ten years with specific prescription of silvicultural treatments - thinning or regeneration harvests. CFUGs are supposed to follow schedule in the plan for various silvicultural operations (MoFSC, 2000). However, they usually apply thinning and pruning whenever they need forest products, mostly for subsistence use (Ojha, 2001). It is still unclear how results of a forest inventory are used on making decisions about the implementation of silvicultural operations in community forests. With transformations in the use of, and expectations from, forests and harmonizing people's needs with forest conditions, there is a need for appropriate application of forest inventory in designing silvicultural operations. To contribute on both economic and ecological outcomes of community forest management, we especially focus to;

a) assess the roles of inventory-based management plans in deciding silvicultural prescriptions

b) assess the deviation of the silvicultural operations actual from the that of prescribed in management plan

c) examine the role of stated silvicultural practice in bringing the change in forest conditions

Hence, with the support of the long-term data of past eleven years of Terai community forest, we explore how the recommended silvicultural prescriptions and actual practices bring changes in the forest conditions. 


\section{Materials and methods}

\section{Study area}

The research was conducted in Kankali CFUG, in the Chitwan district, which is one of the tropical districts of Nepal. This site was selected based upon the existence of multiple forest inventories data $^{4}$. The forest is located at $27.65^{\circ} \mathrm{N}, 84.57^{\circ}$ $\mathrm{E}$ in Khairani municipality covering 749.18 ha area (Fig. 1). Out of the total area,103.48 ha is classified as sensitive area and 645.65 ha as general forest area. The forest is dominated by tropical Shorea robusta species and facing towards to south. The other associated species are Semecarpus anacardium, Holarrhena pubescens, Terminalia alata, Dalbergia sissoo, etc.

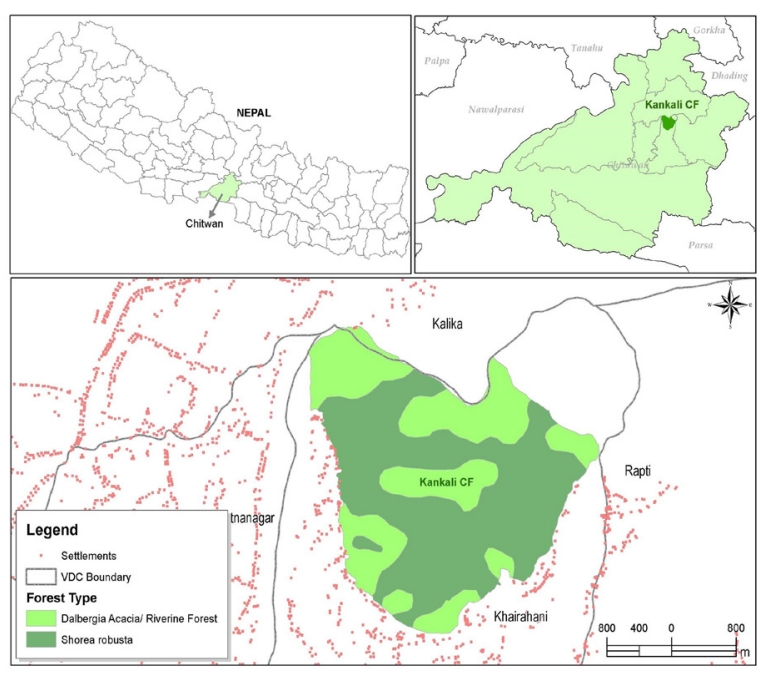

Fig. 1: Study site

The forest is divided into 5 blocks of 99.8 ha to 191.44 ha for forest management proposes. The community, comprising of 1967 households, is managing the forest with both long and shortterm objectives. The long-term objectives are to fulfil the need of forest product of the community and maintain ecosystem, enhance biodiversity through scientific forest management; and improve the livelihoods of the users (Kankali CF, 2013). Likewise, the short-term objectives are to maintain a continuous supply of forest products without degrading forest condition, control forest encroachment, control erosion, control open grazing, promote income generation activities, etc (Kankali CF, 2013).
Table 1: General characteristic of the study site

\begin{tabular}{ll}
\hline CFUG handed over & 1995 \\
$\begin{array}{l}\text { Operational plan revised } \\
\text { on }\end{array}$ &
\end{tabular}

Forest origin

Natural Forests

Altitude of the forest

220-580 $\mathrm{m}$ above mean sea level

Aspect South

Forest Area $\quad 749.13$ ha

Forest type Shorea robusta $(\mathrm{Sal})$

dominated; other

associated species-

Semecarpus anacardium,

Lagerstroemia parviflora,

Holarrhena pubescens,

Buchanania latifolia

Forest development stage Pole size dominated

Number of management 5

blocks

Number of households 1967

Source: Management Plan of Kankali CFUG, Chitwan

(2016)

\section{Research methods}

The study used a case study approach to explore a single phenomenon in a natural setting using a variety of methods to obtain in-depth knowledge (Collis \& Hussey, 2009). It relies on long-term panel data of the ComForM Project of three consecutive periods $(2005,2010$ and 2013) and the data collected in 2016 by the principle author using the ComForM guideline. The project had established 68 permanent plots in the community forest according to the principles of stratified random sampling described by Meilby et al., (2006) using coffee-house methods (Müller, 2001). The detailed process of plot establishment is also explained in Puri et al. (2012). However, the study only considered 60 plots as 8 plots were permanently damaged because of the reason which is beyond the control of the CFUG. Parameters measured included tree measurement, dbh, height, tree condition, social status, and regeneration condition. In addition, interviews with the past and present executive committee members, forest guards and user group staff were conducted to understand the silvicultural operations they have been practising. The interviews were taken during late 2016 and early 2017.

\footnotetext{
${ }^{4}$ Community-based Forestry in Nepal Himalaya Project (ComForM) is the long-term research project implemented by the Institute of Forestry, Pokhara
} 
Four-time series data sets of forest inventory (2005, 2010, 2013 and 2016) were analysed focusing on the type and size of the trees removed from the forests, forest stand condition and sampling and regeneration conditions. Written documentations, such as forest inventory results, management plans, forest products extraction records, financial records, and meeting minutes from the forest user committees were also analysed. The study conducted a content analysis of the management plan to understand the basis for the decisions made on silvicultural operations along with field observations. In the content analysis key contents, such as (a) planning processes (b) silvicultural operations prescriptions and (c) basis for prescriptions are used. After the content analysis, stakeholder consultations, especially with the government forest officials, the forest users, executive members, persons involved in the operations, and the CFUG staff were carried out to understand about practices of silvicultural operations in the plan, problems encountered and effect of different operations on forest management.

\section{Results and discussions}

\section{What is the role of inventory-based management plan in framing silviculture prescriptions.}

Silvicultural prescriptions should be guided by the management objectives while considering the forest stand conditions. Forest inventories are drawn up every ten years to examine the conditions of a CF during the revision of its management plan. Data are collected on tree measurement (dbh and height) and regeneration conditions. From that data, annual increment is calculated and, considering the forest type, $40-60 \%$ of annual allowable cut is confined, but if it exceeds $178 \mathrm{~m}^{3} / \mathrm{ha}$, then a limit will be set within that number. However, in this case study, neither inventory results nor management objectives were discussed while deciding about the implementation of silvicultural operations. Though a forest inventory was prepared, it was simply used as a guide on defining the allowable harvest/selective thinning from the forest. Inventory is considered as one of the prerequisites or administrative requirements for the approval of management plans. Cedamon, et al. (2016) observes that inventory is not used to identify the silvicultural operations that are needed based on the forest assessment results, but only to limit the harvest (Toft, et al., 2015). For instance, the chairperson of a community forest said, "we could hardly distinguish any difference between the plans; it appears almost identical to the previous version." The use of inventory results as a guideline to decide about silvicultural operations could not be understood. A similar practice was also identified by Toft, et al. (2015) and Rutt, et al. (2014) in community forests in the mid hill region of Nepal. Forest management plans are needed by users for ensuring their access to forest resources. One CFUG, executive member said that "no forest management operation can be carried out without a plan, but plans are prepared at the eleventh hour or after it has expired. Furthermore, they only do minor editing of the existing plan instead of carrying out a detailed analysis and interpretation of the inventory data."

The revised Forestry Inventory Guidelines 2004 prescribes the nature of the activities that are to be carried out according to the forest conditions. The nature of intervention should differ by forest conditions (Table 2). However, it was hardly considered while prescribing interventions. Furthermore, proposed silvicultural operations were very generic in nature and looked almost similar irrespective of the block. Same interventions were followed in all forests, questioning the rationality of silvicultural operations and the need for a forest inventory. This further raised a question on the need for the block division itself. It was carried out for managerial reasons, especially for regulating harvesting rather than for managing forests sustainably. Furthermore, silvicultural operations were confined within a small area of the block (annually 10 ha in each block where harvesting is done). Forest inventory guidelines indicate that forests should be divided into blocks based on their conditions; however, in practice, block divisions are made without following any parameters. Overall, (Table 2) the prescriptions laid down in the management plan were followed only to meet the formality to approve the plan and failed to interlink themselves with the forest inventory results. According to users, a visual method was used to identify which trees were fit to be cut, considering the tree-to-tree distance, species, size, appearance, and structure of the 
Table 2: Silvicultural Interventions recommended in guidelines and in actual practice

\begin{tabular}{|c|c|c|c|}
\hline $\begin{array}{l}\text { Forest stand } \\
\text { conditions }\end{array}$ & No of blocks in CF & $\begin{array}{l}\text { Recommended in Community Forest } \\
\text { Inventory Guidelines, } 2004\end{array}$ & $\begin{array}{l}\text { Actual practice by } \\
\text { communities }\end{array}$ \\
\hline Good & 3 & Selection felling, Singling & $\begin{array}{l}\text { Selection felling ( } 4 \mathrm{D} \\
\text { removal), Cleaning }\end{array}$ \\
\hline Moderate & 2 & $\begin{array}{l}\text { Natural regeneration, singling, } \\
\text { weeding and cleaning }\end{array}$ & $\begin{array}{l}\text { Selection felling ( } 4 \mathrm{D} \\
\text { removal), Cleaning }\end{array}$ \\
\hline
\end{tabular}

tree.

The prescribed silvicultural operations fail to address contextual specifications (forest conditions, species composition, and management objectives) and varied within and between blocks. The silvicultural operations were simply listed activities appended to the plan which were to be carried out in a block every year, but they were silent on what, how and where they were to be carried out. It could be because local communities and forest technicians lack specific knowledge of silvicultural treatment (Yadav, et al., 2009). They simply apply tree improvement practices once a year mostly for the fulfilment of basic needs and suggest protection in the remaining blocks. Cleaning and thinning are prescribed in the management plan by referring to the thinning guidelines of the Department of Forests. However, using of additional guidelines by forest users is not practical.

The content analysis of management plan showed that (Table 3 ) the same silvicultural operations were prescribed throughout blocks. The plan recommended conducting of different silvicultural activities such as cleaning and described what and when to be done, but the element, how it has to be carried out was missing. In addition, the prescribed area for silvicultural operations was the same, i.e. 10 ha, irrespective of plot size. It shows only maximum 20 ha of forests received silvicultural operations during the period of ten years, the whole tenure of operation plan in a block, while the size of the block was more than 100 ha. As a result, a large area of land in a block remained untouched. This apparently raised concerns on the usefulness of the silvicultural operations itself. Silvicultural operations need to be designed in a way, that it is possible to cover the entire forest or a particular area of the forest in a given time frame to improve the conditions. This has happened mostly because management objectives were not defined at the time of selecting silvicultural operations. It merely appears as one of the basic ingredients of the management plan. The plan merely appears as a paper tool so that technician guide and forces users to do what they think are correct (Rutt, et al., 2014 and Toft, et al., 2015).

\section{Are silvicultural operations prescribed in the management plan followed?}

The silvicultural operations are manipulated, and do not follow the forest inventory guidelines and management plan. Whatever is written in the management plan is partially followed (Table 4). The management plan prescribes conducting silvicultural operations during NovemberFebruary; however, such activities are not taking place as is prescribed. This is because of administrative procedures required for conducting silvicultural operations, especially for thinning

Table 3: Silvicultural Operations prescribed in the management plan

\begin{tabular}{llccc}
\hline Block No & Silvicultural Operations & $\begin{array}{c}\text { Block Area } \\
\text { (Ha) }\end{array}$ & $\begin{array}{c}\text { Prescribed Area for } \\
\text { Silvicultural Treatment } \\
\text { (Ha) }\end{array}$ & $\begin{array}{c}\text { Prescribed } \\
\text { Year (AD) }\end{array}$ \\
\hline 1 & Cleaning, Thinning & 151.9 & 10 & 2012,2017 \\
2 & Cleaning, Thinning & 127.9 & 10 & 2013,2018 \\
3 & Cleaning, Thinning & 178.1 & 10 & 2014,2019 \\
4 & Cleaning, Thinning & 191.4 & 10 & 2015,2019 \\
5 & Cleaning, Thinning & 99.8 & 10 & 2016,2020 \\
\hline
\end{tabular}

Source: Management Plan of Kankali CFUG, Chitwan (2016) 
and selective harvesting. For instance, cleaning is prescribed during November-February, but these activities are not taking place as scheduled. Likewise, thinning is practised as removing only 4Ds (dead, diseases, dying and deform trees); however, users are also harvesting other categories of trees to fulfil their subsistence needs. Silvicultural operations are simply cleaning of the forest after harvesting and selective felling of trees marked by forest officials. It might also be due to poor technical and post-formation support from district officials. In reviewing the management plans of seventy-six CFUGs in the western regions of the terai, Bhattacharya \& Basnyat (2003) conclude that silvicultural operations are complex and not in detail; so, it is difficult for users to follow them. Furthermore, they fail to address management objectives.
They, moreover, focus on the activities that are to be carried out in a particular block and year, but neglect to spell out methods for conducting such activities; so, instead of being prescriptive, silvicultural operations are descriptive.

Many activities are prescribed for being conducted at the time of harvesting and that, too, within selected blocks. As the management plan only suggests what is to be done and when it is to be done but is silent on how to do, this has created confusion among users (see box 1). One of the CF leaders says, "every other year, new forest officials come up with their own ideas and impose opinions based on either their own interests or government circulars. This has created confusion and delayed the process." In a nutshell, silvicultural operations are de jure

Table 4: Deviation between recommended silvicultural prescriptions in the management plan and actual practice

\begin{tabular}{lll}
\hline Silvicultural Prescriptions & Recommendation & Actual Practices* \\
\hline Cleaning/ Weeding & $\begin{array}{l}\text { Removal of undesired species in the } \\
\text { month of November to February }\end{array}$ & $\begin{array}{l}\text { Partially practice; Cleaning carried out in } \\
\text { one block every year which is in rotation } \\
\text { of harvesting of forest products. However, } \\
\text { cleaning does as per prescribed schedule }\end{array}$
\end{tabular}

Singling (from the coppice Singling will be carried out in Not practice; No singling activities were or from numerous seedling) the blocks where cleaning was carried out during the God-mel(cleaning), conducted during November to but dense number of seedling/saplings February. It has to be conducted of undesired/ less valuable species were every year

removed at the time of cleaning.

Users follow their own judgement as there is no definite rule applies

Pruning

Thinning/ Selective felling/ harvesting

Mother tree
No pruning; Should be carried out Removal of lower branches and dead in the presence of forest officials

Removal of 4Ds trees are given priority with considering ecological and biological sensitivity

For harvesting of trees approval should be taken from DFO office

The timber harvesting should limit within annual allowable harvest. firewood or fodder which result also for canopy opening

Removals are mostly 4Ds (dead, dying, diseased and deformed/broken trees/ poles) however sometime harvest green and good trees to fulfil the users' demands and which support on opening of crown

Approval is being taken in advance from the DFO

DFO staff determined the trees to be felled and marked with considering the annual allowable harvest.

Mother trees are identified and Users are aware of mother tree concept; marked however, only over matured tree are kept as mother tree

Source: Management Plan of Kankali CFUG, Chitwan (2016); * derived from the experience of community forest user committee members 
recommended in the inventory guidelines and operational plan, but they do not de facto take place. This corroborates with Meilby, et al. (2014), which observes that most of the revision work or sometimes technicians are responsible for preparation of plans itself, so that they limit the silvicultural operations to be carried out even though they are listed in the plan.

\section{Box: 1. Whom should we trust? Users' dilemma over silvicultural prescriptions}

Forest users are responsible for preparing management plans by considering all silvicultural operations to be carried out and submit them to the District Forest Office concerned for approval. However, it goes on other ways. Users do not refer to the prescriptions in the plan and often do not tend to follow the prescriptions proposed in it, considering that technicians have limited knowledge of the subject-matter or do not understand the specific context or are scared of losing the forest they have developed. They merely do on their own considering local practices. Whatever is written in the management plan is simply a paper tiger to convince others that they have a plan and that they are managing the forest according to the management plan.

Whatever prescriptions are in practice are in blanket approach "fit to all" (Gelo and Koch, 2012). The management plans prescribe all silvicultural operations needed for forest management, but only selective felling (removal of dead, dying, diseased and deformed trees), singling and cleaning are practised (Cedamon, et al., 2016). Moreover, the inventory results for deciding silvicultural operations are found to have failed to relate to the forest contextual conditions, which is due to either lack of proper inventory or ambiguity of the inventory for making a decision of forest management. Almost all silvicultural operations prescribed are identical (Bhattacharya \& Basnyat, 2003 and Toft, et al., 2015); so there is no use of forest inventory.

\section{How current silviculture practices are brining change in the forest stand conditions}

The time series analysis showed that the species composition was changing over time (Fig. 2). Among the top five tree species, Shorea robusta, Lagerstroemia parviflora, Semecarpus anacardium, Holarrhena pubescens and
Buchanania latifolia, the population of S. robusta continuously increased during the time period. However, the share of the other species gradually decreased. The results show that the relative frequency of $S$. robusta was high and increased from 68 in 2005 to almost 71 in 2016, while that of other species was very low and indicated a decreasing trend. The change in species composition is due to the preference given by the communities to conserving economically valuable species and discarding other species with low value. As a result, the forest was gradually converting into a $S$. robusta dominated single species-focused management from mixed forest management despite the fact that one of the main objectives of forest management is maintaining forest tree diversity. So, it seems that management operations follow a different set of management objectives compared to those defined in the management plan. In a study of six CFUGs in mid-hills of Nepal, Cedamon, et al. (2016) conclude that the current silviculture operations pose a threat to species diversity and understanding the forest stand structure is crucial to providing a basis for silvicultural interventions to be prescribed in case of multiple products and services management.

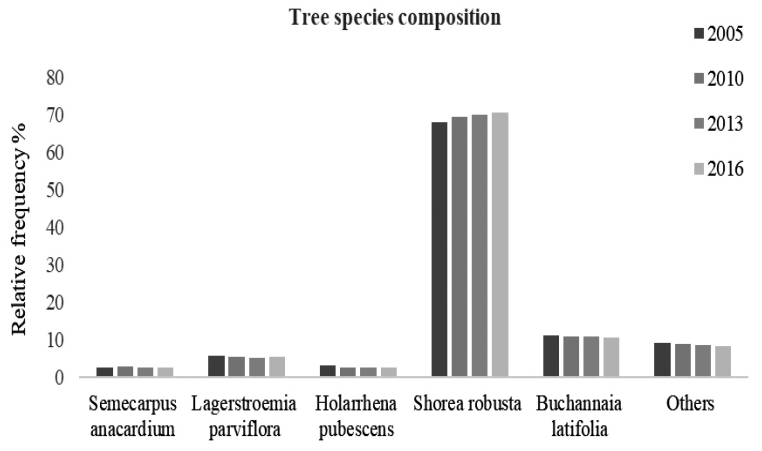

Fig. 2: Relative frequency [\%] of tree species in the community forest

Forests are dominated by pole trees, with very limited number of saplings, $169.57 \mathrm{~N} /$ ha in 2016 , which is much less than that prescribed by the Community Forestry Inventory Guidelines 2003 (Table 5). The Community Forestry Guidelines 2004 prescribes that a forest should have more than 2,000 per ha to be in good sapling conditions and those that are less than 800 ha are of poor quality (independently from the tree species considered). The pole-sized trees were mostly removed consistently over all four periods, while there was a marginal improvement in the 
number of trees per ha. Analysis of $S$. robusta in comparison to other associated species showed that poles of other species were removed by 28 per cent than that of $S$. robusta, and the number of poles had decreased for all species, which might be because of selective harvesting practices in community forests. Users preferred $S$. robusta trees to other species. Nevertheless, the number of stems per ha had decreased among all species; however, the rate of decline was higher in other species than in $S$. robusta forests. The objective of the management plan was to stop degradation of the forest and improve its stand conditions. If management went on like this, the forest might force to turn towards corpse, with limited growth and retard quality trees (DFRS, 2015). It shows that, without taking out mature trees and properly maintaining the distance between poles, all the forests will produce fuelwood of economically valuable species instead of high quality timber in the future. On the other hand, seedlings are merely grow into saplings; regeneration seems very good; nevertheless, very few are established into saplings. Saplings in 2005 were very poor and, in due course of time, their number decreased very sharply, from 623.6 to 169.57 stand density per ha.. If it continued like that, there would be no second generation trees, and again community would have to wait for another forty or fifty years to get good timber. Rutt, et al. (2014), a study in high and mid-hills of Nepal, also draws out similar findings. A proper silvicultural operation considering citizen science and scientific knowledge is very crucial for the management of economically valuable terai forests. The current silvicultural operations prescribed in the plan in a blanket manner without their appropriate implication in practice fail to typify the needs of specific stand condition enhancement of the forest and meet the objective of economic returns in the long run.
Furthermore, trees are harvested in a scattered and haphazard manner without considering the individual requirements of tree species. This may further impact the growth of economically important trees since the operations are carried out without considering the tree species targeted in the management. The Inventory Guidelines 2004 state that a 10 to $29.9 \mathrm{~cm}$ diameter class belongs to the pole category. The stand density analysis shows that pole trees are dominating. Forest stand with regeneration ensures good health and composition of the forest, but the establishment of regeneration to sapling is the most important parameter to assess the forest health, which was lagging in our study site.

Forest condition is broadly defined based on the growing stock volume and regeneration and sapling conditions, measured in terms of the number of seedlings and saplings per ha (Poudel, et al., 2014). However, a circular of September 30,2012 explicitly notes that the national average of growing stock volume should be below 178 $\mathrm{m}^{3} / \mathrm{ha}$, which was also approved by the Ministrial cabinet meeting of May 23, 2011. It further indicates that the annual increment should be maintained between $1.5 \%$ and $2 \%$ in the case of slow-growing species. Seemingly, it shows that, along with a forest inventory, there are several government forest decrees and circulars which also impact the current conditions of the forests, as well as silvicultural prescriptions rather than taking into account contextual conditions. Terai forests are sparse but valuable where protection and silvicultural operations enhance the ecology and economic output of the forest (Poudel, et al., 2015). The current management practice might cause huge economic and ecological losses in the absence of appropriate practices to interpret the inventory results and adapt silvicultural operations in considering the stand-specific context.

Table 5: Tree species density in the community forests

\begin{tabular}{lrrrrrr}
\hline $\begin{array}{c}\text { Species Categories } \\
\text { (DBH class cm) }\end{array}$ & \multicolumn{3}{c}{ Overall tree (Stem density/ha) } & \multicolumn{2}{c}{$\begin{array}{c}\text { Change \% between 2005 } \\
\text { and 2016 }\end{array}$} \\
\cline { 2 - 5 } & $\mathbf{2 0 0 5}$ & $\mathbf{2 0 1 0}$ & $\mathbf{2 0 1 3}$ & $\mathbf{2 0 1 6}$ & $(10882.40)$ & $(39.68)$ \\
Seedling (below 2) & $27,426.5$ & $28,308.8$ & $21,764.8$ & $16,544.1$ & $(72.81)$ \\
Sapling (2-9.9) & 623.6 & 473.08 & 342.83 & 169.57 & $(454.03)$ & $(72.83)$ \\
Pole (10-29.9) & 412.70 & 377.37 & 361.67 & 337.33 & $(75.37)$ & $(18.26)$ \\
Tree (30-49.9) & 15.0 & 15.0 & 15.0 & 20.30 & 5.30 & 35.33 \\
Mature Tree (>50) & 8.33 & 8.33 & 9.33 & 10.0 & 1.67 & 20.05 \\
\hline
\end{tabular}

Source: Inventory result of 2005, 2010, $2013 \& 2016$ 


\section{Conclusion}

From the above results and discussion, we conclude that silvicultural operations should be guided by the management objectives, forest stand conditions and other site-specific factors, such as forest type and topography. However, it is only appended to the plan as a prerequisite with little practical relevance to the forest management decisions. Silvicultural operations are recommended in blanket approach in the inventory guidelines and the operational plan, but they are not actually being implemented in practice. Both users and forest officials consider it as one of the necessary ingredients of the plan but low emphasis in implementation.

Community forests were handed over to communities with the objective of improving the degraded forest so that silvicultural operations prescribed were merely focusing on planting and protection planting of suitable trees. It is already four decades since we started conserving our forests, the practice is still the same despite of good forest cover and stock. Despite of what is stated in the plan; users mostly focus on the collection of fuelwood, fodder, leaf litter and harvesting of timber, in practice. On the other hand, forest technicians merely think of enhancing resource conditions and exploring appropriate management practices based on forest condition, composition and physiography. As a result, silvicultural operations prescribed in the plan are very general and descriptive, allowing to fulfill many possible combinations of management objectives.

Our study concludes that present forest inventory does not support the deciding on silvicultural operations in forest management. Silvicultural prescriptions are just an appended to the management plan. In fact, they should be defined by considering the site quality, actual forest condition and socio-economic situation of the forest dependent communities. Hence, with the shifting needs of communities towards priorities other than collection of fuelwood and fodder, it urges introducing "adaptive silvicultural operations" by considering both ecological and economic context. The silvicultural prescriptions should not be civic-centric (simple pictorial form) rather than techno-centric (complex). A "civic-centric" adaptive forest management practice with considering the local context by the local should be in used. Hence, for ensuring future economic and ecological sustainability of community forests, forest management should not only be output-oriented but also be processoriented.

\section{References}

Acharya, K. P. 2002. Twenty-four years of community forestry in Nepal. International Forestry Review 4 (2): 149-156.

Acharya, K. P. 2003. Conserving biodiversity and improving livelihoods: The case of community forestry in Nepal. Paper presented at The International Conference on Rural Livelihoods, Forests and Biodiversity 19-23 May 2003, Bonn, Germany.

Bartlett, A. G. 1992. A review of community forestry advances in Nepal. The Commonwealth Forestry Review 95-100

Basnyat, B. and Bhattacharya, A. K. 2006. Forestry for Next Decade: Managing Thrust Area. In Bhattacharya, A. K. (Eds.), Efficacy of Community Forestry Operational Plans in Bio-diversity Conservation: A study from Western Terai region of Nepal (pp. 542-554). Delhi, India: Concept Publishing House.

Bhattacharya, A. K. and Basnyat, B. 2003. An analytical Study of Operational Plan and Constitutions at Western Terai Region of Nepal, Banko Jankari Vol 13 (1) pp 3-14,

Branny, P. and Yadav, K. P. 1998. Changes in community forest condition and management 1994- 1998: Analysis of information from the forest resources assessment study and socioeconomic study in the Koshi Hills. Nepal UK Community Forestry Project. Project report G/NUKCFP/32, Kathmandu, Nepal.

Cedamon, E., Nuberg, I., Paudel, G., Basyal, M., Shrestha, K., Paudel, N. 2016. Rapid Silviculture Appraisal to Characterise Stand and Determine Silviculture Priorities of Community Forests in Nepal. Small-scale Forestry DOI 10.1007/s11842-016-9351-0.

Collis, J. and Hussey, R. 2009. Business Research: A practical guide for undergraduate and postgraduate students, 3rd edition, New York, Palgrave Macmillan. 
DFRS, 2015. State of Nepal's Forests. Forest Resource Assessment (FRA) Nepal, Department of Forest Research and Survey (DFRS). Kathmandu, Nepal.

DoF. (2000). Circular dated February 2000. Department of Forests (DoF), Government of Nepal. Kathmandu, Nepal.

FAO, 2017. http://www.fao.org/sustainableforest-management/toolbox/modules/ silviculture-in-natural-forests/basicknowledge/en/ cited on 14 February 2017.

Gautam, A. P., Shivakoti, G. P., and Webb, E. L. 2004. Forest cover change, physiography, local economy, and institutions in a mountain watershed in Nepal. Environmental management 33 (1): 48-61.

Gelo, D and Koch, S. F. 2012. Does one size fit all? Heterogeneity in the valuation of community forestry programs. Ecological Economics 74, pp 85-94.

Gilmour, D. 2016. Forty Years Community Based Forestry. A review of its extend and effectiveness. Food and Agriculture Organization United Nations. Rome. Italy.

GoN, 1993. Forest Act, 1993. Government of Nepal (GoN),Official English Version (Kathmandu). Nepal.

GoN, 1995. Forest Regulation, 2051 (1995). Government of Nepal (GoN), Official English Version (Kathmandu). Nepal

Hobley, Mary. 1996. Participatory Forestry and the Process of Change in India and Nepal. Rural Development Forestry Study Guide 3, Rural Development Forestry Network, Overseas Development Institute, London. UK.

Hara K. L. O', 2016. What is close-to-nature silviculture in a changing world? Forestry: An International Journal of Forest Research. 89(1): 1-6, doi:10.1093/forestry/cpv043

Maryudi, A., R. Devkota, C. Schusser, C. Yufanyi, M. Salla, H. Aurenhammer, R. Rotchanaphatharawit and M. Krott. 2011. "Back to basics: considerations in evaluating the outcomes of community forestry." Forest Policy and Economics 14, Vol. 4: 1-5.
Meilby, H., Smith-Hall, C., Byg, Anja., Larsen, H. O., YSTEIN UUL Nielsen, Ø. J., Puri, L., Rayamajhi S., 2014. Are Forest Incomes Sustainable? Firewood and Timber Extraction and Productivity in Community Managed Forests in Nepal, World Development, http:// dx.doi.org/10.1016/j.worlddev.2014.03.011.

Meilby, H., Puri, L., Christensen, M. and Rayamajhi, S. 2006. Planning a system of permanent sample plots for integrated longterm studies of community-based forest management. Banko Janakari 16 (2): 3-11.

MFSC.2000. Guideline for Inventory of Community Forests. Ministry of Forests and Soil Conservation (MFSC), Department of Forests, Community and Private Forest Division, Kathmandu, Nepal.

MFSC. (2014). Annual Performance Evaluation of District Forest Officer, 2014. Nepal: Ministry of Forest and Soil Conservation, Nepal. (MFSC), Kathmandu, Nepal.

MFSC. (2014a). Forest Policy 2014. Nepal: Ministry of Forest and Soil Conservation, Nepal, (MFSC), Kathmandu, Nepal.

MFSC. (2016). Forest Sector Strategy, 2014. Nepal: Ministry of Forest and Soil Conservation (MFSC), Kathmandu, Nepal.

Müller, W. G. 2001. Collecting Spatial Data: Optimum Design of Experiments for Random Fields. Heidelberg: Physica-Verlag.

Ojha H. 2001. Silviculture in community forestry: conceptual and practical issues emerging from the middle hills of Nepal. Banko Janakari 11: 20-23.

Pokharel, B. K., Braney, P., Nurse, M. and Malla, Y.B. 2007. Community Forestry: Conserving Forests, Sustaining Livelihoods and Strengthening Democracy. Journal of Forest and Livelihood 6 (2): 8-19.

Poudel, N. R., Fuwa, N., and Otsuka, K. 2015. The impacts of a community forestry program on forest conditions, management intensity and revenue generation in the Dang district of Nepal Discussion Paper: 13-24. National Graduate Institute for Policy Studies. 7-221 Roppongi, Minato-ku, Tokyo, Japan 1068677. 
Puri, L., Meilby, H., Rayamajhi, S., Timilsina, Y. P., Gautam, N. P., Subedi, R., \& Larsen, H. O. 2012. Growth and volume based on permanent sample plots in forests managed by communities. Banko Janakari, 22 (2), $11-18$.

Rutt R, Chhetri B, Pokharel R, Rayamajhi S, Tiwari K, Treue T. 2014. The scientific framing of forestry decentralisation in Nepal. For Policy and Econ 60: 50-61.

Toft M, Adeyeye Y, Lund J. 2015. The use and usefulness of inventory-based management planning to forest management: evidence from community forestry in Nepal. For Policy and Econ 60: 35-49.

Wang, S. 2004. One hundred faces of sustainable forest management. Forest Policy and economics (6): 205-213 Pacific Forestry Centre, Canadian Forest Service, Natural Resources Canada, 506 West Burnside Road, Victoria, BC, Canada V8Z 1M5
Yadav N, Yadav K, Yadav K, Thapa N. 2009. Facilitating the transition from passive to active Facilitating Transition from Passive to Active Management of Community Forests in Nepal: Lessons from Livelihoods and Forestry Programme. Forest Action Discussion Paper 2009/7.

Yadav N, Yadav T, Thapa Y. 2011 Active Forest Management as a Means for Promoting Economic Development and Poverty Reduction in Community Forest User Groups, Nepal, http://www.forestrynepal. org/publications/article/5309. Accessed 20 May 2014. 